\title{
BRAND SWITCHING BEHAVIOUR IN THE GENERATION Y: EMPIRICAL STUDIES ON SMARTPHONE USERS
}

\author{
Indah Fintikasari ${ }^{1}$, Elia Ardyan ${ }^{2 *}$ \\ ${ }^{12}$ Sekolah Tinggi Ilmu Ekonomi Surakarta, Central Java \\ *Corresponding author; Email: ardyan.sbs@gmail.com
}

\begin{abstract}
Lifestyle, variety seeking, customer trust and promotion are some factors that can be a trigger. The sample of respondents used in this study is 385 respondents' smartphone users who have experience of brand switching, while the analysis of this study using structural equation modelling (SEM) and to process this research data used AMOS version 20. The result indicated that lifestyle and variety seeking is able to increase brand switching, especially on smartphone product users. Consumer trust in a particular brand still unable to reduce their desire to switch brand significantly, another result also indicated that promotion unable to increase the desire to switch brands.
\end{abstract}

Keywords: Lifestyle, seeking variety, customer trust, brand switching, generation Y.

\section{Introduction}

Brand switching is an important topic in the context of generation Y. Generation Y is difficult to loyal to a particular brand (Syrett \& Lammiman, 2004). Parmen (2013) explained about the comparison of loyalty to retail between generation Y and baby boomer, loyalty to retail in generation $\mathrm{Y}$ is lower compared with baby boomer. Y generation is easier to switch brand. One of the products that has a short lifecycle is the smartphone. Almost every month the company is trying to launch new products. It is because of the lifestyle of consumer who always demands something new. The result of Viswanathan and Jain (2013) study finds that generation $Y$ has a short-term point of view in terms of purchasing and decision making to consume a product, they also explains that generation $Y$ will replace its product once every three months.

Basically, the meaning of brand switching is to move loyalty from one brand to another by the customer. Brand switching indicates that the original brand is no longer attractive (Al-Kwifi \& Ahmed, 2015). Customer prefers to switch to more attractive brands (Ping, 1993). Anderson and Sullivan (1993) explain when consumer switches to another brand, it because the strategy developed is not able to maintain or motivate existing consumers. Several other studies explain some of the factors that trigger brand switching behaviour is as follows competition, behaviour and time (Srinivasan \& Ratcford, 1991), interpersonal relationships, marketing strategies (Wathne, Biong \& Heide, 2001), and customer seeking for variety (Arianto, 2011).

To understand the different variety of brand switching factor is essential to create a business strategy (Al-Kwifi, Ahmed \& Yammout, 2014). Shukla
(2004) explained that by analysing the cause of brand switching, the manager will be able to repress the decline happened and build a successful company. According to (Peter, 1987), it would be more profitable if the company maintain the existing customer rather than find new customers. The company inability to maintain customer will result in a decline in the image of the company (Lopez, Redondo \& Olivan, 2006). There are two things that should become the main concern of marketers in an effort to reduce brand switching behaviour, that is, pay attention to the pattern of the customer in using the brand and the level of satisfaction of the product (Shukla, 2004).

It is important to understand brand switching from the generation Y point of view. Only a few studies discuss brand switching from generation $\mathrm{Y}$ point of view, mostly focusing on brand loyalty in generation Y (Lazarevic, 2012) or decision making in generation Y (Solka, Jackson \& Lee, 2011; Viswanathan $\&$ Jain, 2013). The purpose of this study was to examine the factor that becomes a trigger of brand switching on generation Y, particularly in the smartphone industry. Factors that become triggers are as follows: lifestyle, variety seeking, customer trust, and promotion. The result of this study will give a good contribution either theoretical or managerial.

\section{Relationship between Life Style and Brand Switching}

Lifestyle is an important aspect in marketing. Generally, lifestyle in the marketing is used to conduct market segmentation (Plummer, 1974; Valentine \& Power, 2013). From various references, Gonzalez and Bello (2002) concluded that definition of lifestyle is how individuals spend their time and money. Mow- 
en and Minor (2002) concluded that lifestyle is a way of life, spend money and allocate time. Solomon (2011) explained that lifestyle includes four dimensions, such as activities, opinion, interest, and demography. The activity is usually a daily activity that is conducted in the person's life. The activities in lifestyle include job, vacation, internet, sport, shopping, and others. The opinion consists of issue that exist in the social and politic environment, products and culture. Interest is part of lifestyle such as family, job, fashion, media, and others. Demography can be income, age, family business and others.

Lifestyle closely related to a personal chooses to make a purchase. Lifestyle is a consumer behaviour measurement (Khrisnan, 2011), particularly in brand choice. Khan and Nasr (2011) found a significant relationship between lifestyle and brand choosing (Lin \& Shih, 2012). Lifestyle is able to influence the decision in choosing a brand, when a brand is not suitable with customer lifestyle, the customer can be easy to choose another brand which represented their lifestlye.

$H_{1}$ : Lifestyle has a positive influence and significant toward brand switching

\section{Relationship between variety seeking and brand switching}

The various study explains about variety seeking buying tendency (Kahn, 1995; Menon \& Kahn, 1995; Steenkamp \& Baumgartner, 1995; Van Trijp, Hoyer \& Inman, 1996). Variety seeking is defined as individual tendency to find diversity in their choice of service or goods (Kahn, 1995). Variety seeking is divided into two types, which is derived and direct seeking variety behaviour (McAlister \& Pessemier, 1982). Derived seeking variety behaviour is searching a variety of alternative options that are triggered by external environmental changes rather than internal motivation (Ha \& Jang, 2013), while the direct seeking variety behaviour is explains as a direct motivation intrinsically and explained by the optimal stimulation level (OSL) theory (Jang \& Feng, 2007; Menon \& Kahn, 1995; Van Trijp et al., 1996).

Van Trijp et al. (1996) explained that one of the causes of consumers doing variety seeking is due to boredom or saturation in a brand. Jang and Feng (2007) explained that consumer is searching for something new due to boredom in a certain brand. There is an explanation that consumers are tired not on its brand but on product attributes (Inman, 2001). In addition, the desire for a maximum stimulated become a trigger for customers for finding a various alternative in purchases (Steenkamp \& Baumgartner, 1995). The desire for a maximum stimulated is the cause of consumers searching for something different (Menon \& Kahn, 1995; Van Trijp et al., 1996) that make consumer easy to switch brand. Variety seeking behaviour is the main trigger for the consumer to switch brand (Rajagopal, 2005). The availability of a wide range of product variations of different types of brands can be a trigger to try, that will make consumer not entirely loyal to a certain brand.

$\mathrm{H}_{2}$ : Variety seeking has a positive impact and significant toward brand switching

\section{Relationship between Trust and Brand Switching}

Trust is the most important concept when discussing generation Y. Chen and Huang (2013) explained the definition of trust as believing that the information obtained is accurate, transparent and reliable. Soares, Pinho and Nobre (2012) were more focus on our related parties. The core belief is hope and confidence to others. Trust is always associated with a relationship involved, either with other parties or other things (Atkinson \& Butcher, 2003; Greenwood \& Van Buren III, 2010). In this study, trust related to the brand. Lau and Lee (1999) explained that trust on a brand is focusing on the symbol instead of person. Trust is able to increase the loyalty of a person on a particular brand (Lau \& Lee, 1999; Porral \& Levy-Mangin, 2016; Yap, Ramayah \& Shahadin, 2012). A person will not be easy to switch to other brands if they have believed in certain brands.

$H_{3}$ : Trust has a negative and significant effect on brand switching

\section{Relationship of Other Brand Promotion and Brand Switching}

Kotler and Armstrong (2008) argued that promotion mix is a combination of various promotional strategies to give companies maximum results. The strategy promotion means to deliver information and exchange ideas between the sender and the recipient (Belch \& Belch, 2001). Promotional results will have an impact on switching behaviour (Sun, 2005). Kahn and Louie (1990) explained that promotional activeties can cause consumers to change their choices on unfamiliar brands. Some studies provide tools or models that can determine the duration of promotion during the transition period for customers switching do different brands (Lin \& Lin, 2008). Promotion makes brand more than the only product (MaixéAltés, 2010). Promotion is related with contact between the company and its customers (Al-Kwifi \& Ahmed, 2015). Marketers should promote feature 
product as well as its performance. John, Weiss, and Dutta (1999) explained that the feature of a product is a significant factor to increase the user's interest to switch brands. An interesting feature is an advantage in the competition (Al-Kwifi \& McNaughton, 2011) and able to make smartphone users switch brand. In this study, we conclude that the more attractive the promotion is made it will make customers lose their interest to switch to other brands.

\section{$H_{4}$ : Promotion has a negative and significant effect on brand switching}

\section{Research Method}

\section{Sample}

The population in this study were consumers born in 1982-2002 and had the experience of changing the smartphone brand. The purpose of the questionnaire is to obtain quantitative data from consumers. The questionnaire that has been distributed for approximately 400, only 385 questionnaires are filled correctly and can be used for further analysis. Distribution location is in Surakarta, Central Java, Indonesia. The distribution was conducted during December 2016.

Sampling technique used in this research is purposive sampling. Requirements to be respondents in this study are as follows (1) Respondents are limited by age. Based on Muskat, Muskat, Zehrer and Johns (2013), generation $\mathrm{Y}$ is a generation born between 1982 up to 2002 , therefore the sample is limited only by the age of 14-35 years old. (2) They have experience in changing smartphone brand.

Characteristics of respondents are by age, gender, and occupation. The total respondent based on age is as follows: age 14-20 years $=110$ respondents, age $21-25$ years $=200$ respondents, age $26-30$ years $=50$ respondents and age 21-34 years $=25$ respondents. Respondents based on gender are as follows: male respondents $=197$ and female respondents $=188$. More than $44 \%$ respondent are students, college student (172), the rest is employees (50 respondents), PNS (20 respondents), entrepreneur (34 respondents), private employees (60 respondents) and others (46 respondents).

\section{Variable}

This study applies scale measurement, where the scale of measurement used is Five Scale. One explains strongly disagree and five explains strongly agree. In this research, there are two variables, dependent and independent variable. The dependent variable in this research is brand switching, it is adopted from the independent variable, which in this study is a lifestyle, variety seeking, customer trust and promotion.

Endogenous variable in this research is brand switching, which defined as the decision to buy a brand different from usual on the last purchase opportunity (Meixner \& Knoll, 2015). The brand switching indicator was adopted from Sari, Hidayat \& Widiartanto (2014), that is a strong desire to switch brand, unwillingness to use the service, tendency to give up on a brand, tendency to accelerate to discontinuation the brand, prefer another brand and postconsumption dissatisfaction (Mowen \& Minor, 2002).

In this study, the independent variables are a lifestyle, variety seeking, customer trust and promotion. Lifestyle is defined as the of living, spending money and time allocations. This study proposes lifestyle indicators as follows: suitability of needs, pride, social relations, prestige, and rewards. Jang and Feng (2007) defined variety seeking as a consumer who is looking for something new since certain brands are no longer attractive. Variety seeking indicator is adapted from Van Trijp et al. (1996), which is trying something new, challenging to try another brand, confidence to try different brands and enjoying the desire to hunting different brands.

Chen and Huang (2013) explained the definition of trust is the belief that information obtained is accurate, transparent and reliable. Indicators of customer trusts are adopted from Moorman, Deshpande and Zaltman (1993): Trust that the company has provided the correct information about the brand, Trust that the company will responds to customer complaints, Trust that the company will fulfil its promise, and Trust that the product offered is safe or not at risk.

Promotion is the flow of information created to direct a person or organization into action that creates exchanges in marketing (Dharmmesta, 1991). Promotional indicators in this study were adopted from Laksana (2008), promotional indicators in this study were adopted from Laksana (2008), which is advertising messages, media advertising, bonuses, discounts and event creation.

\section{Data Analysis}

AMOS software was used to manage and analyse quantitative data. To examine the model measurement was used validity and reliability. Validity used in this research is loading factor and average variance extracted (AVE), while reliability is tested using composite reliability. The structural equation modelling (SEM) is used to analyse the data. The hypotheses were tested and the results are described in the next chapter. 


\section{Result}

\section{Validity and Reliability Test}

Validity and reliabilities measure to specify the validity and reliability of the instrument using. Validity is measured using loading standard and AVE, while reliability is measured using composite reliability. The loading standard should be more than 0.5 (Nunnally, 1978). In this study, all loading factors are above 0.5 . Terms of validity based on AVE should be above 0.5 (Ghozali, 2013). Table 1 shows that AVE value is more than 0.5 , which is Lifestyle (0.586), Seeking Variety (0.511), Customer Trust (0.502), Promotion (0.615), and brand switching (0.868). Composite reliability is more than 0.6 (Bagozzi \& Yi, 1988). In this study, all variable have composite reliability value greater than 0.6 is Lifestyle (0.887), Seeking Variety (0.807), Customer Trust (0.801), Promotion (0.888), and brand switching (0.868).

\section{Goodness of Fit Examination}

The Goodness of fit in this study is extremely good. There are four indicators of goodness of fit,
AGFI, GFI, CFI, IFI, TLI, and RMSEA. The value of AGFI $(0,841)$, GFI $(0,865)$, CFI $(0.914)$, IFI $(0.915)$, TLI $(0.902)$ and RMSEA $(0,072)$, those are suitable for the requirements and it can be concluded that the model built already fit with research data. The value of GFI and AGFI still in marginal fit.

\section{Hypotheses Examination}

In this study, there are four hypotheses that have been examined. Hypotheses 1 related in this study is lifestyle can increases a person desire to switch brand easily. The result of this research shows that lifestyle can increase a person's desire to switch brands significantly $(\beta=0.191 ; t=2,532 ; p=0.011)$. Hypothesis 1 is accepted.

Hypothesis 2 in this study is variety seeking has a positive and significant influence on brand switching. The result of this study shows that variety seeking is able to increase a person's desire to switch brand significantly $(\beta=-0.030 ; t=-0.432 ; p=0.666)$. Hypothesis 2 is accepted.

Hypothesis 3 in this study is customer trust has a negative and significant influence on brand switching. The result of this study shows that customer trust is

Table 1

Validity and Reliability Test

\begin{tabular}{lcc}
\hline \multicolumn{1}{c}{ Variabel dan Indikator } & $\begin{array}{c}\text { Factor } \\
\text { Loading }\end{array}$ & $\begin{array}{c}\text { AVE } \\
\text { Remposite } \\
\text { Reliability }\end{array}$ \\
\hline LIFE STYLE & & 0.613 \\
Brand in accordance with life style & 0.702 & \\
Brand expresses pride & 0.751 & \\
Brand express social relations & 0.782 & \\
Brand expresses prestige & 0.829 & \\
Brand expresses reward & 0.842 & \\
SEEKING VARIETY & & 0.511 \\
Trying something new & 0.687 & \\
Challenging to trying another brand & 0.747 & \\
Confident to trying different brands & 0.677 & \\
Enjoying the desire in hunting different brands & 0.745 & \\
\hline CUSTOMER TRUST & & 0.502 \\
Trust that the company has provided correct information about the brand, & 0.664 & \\
Trust that the company will respond to customer complaints & 0.686 & \\
Trust that the company will fulfil its promise, & 0.764 & \\
Trust that the product offered is safe or not at risk & 0.716 & \\
\hline PROMOTION & & 0.801 \\
Advertising message & 0.788 & \\
Media advertising & 0.673 & \\
Bonuses & 0.818 & \\
Discounted & 0.798 & \\
Event creation & 0.834 & \\
BRAND SWITCHING & & 0.888 \\
Strong desire to switching brand & 0.707 & \\
Unwillingness to use the service & & \\
Tendency to accelerate to discontinuation the brand & 0.767 & \\
Prefer another brand & 0.834 & \\
Post consumption dissatisfaction & 0.727 & \\
\hline
\end{tabular}


able to reduce a person's interest to switch brand but not significant $(\beta=-0.030 ; t=-0.432 ; p=0.666)$. Hypothesis 3 is rejected.

Hypothesis 4 in this study is promotion has a positive and significant influence on brand switching. The result of this study shows that promotion is able to increase a person's desire to switch brand but not significant $(\beta=0.085 ; \mathrm{t}=1.160 ; p=0.246)$. Hypothesis 4 is rejected.

Table 2

Hypotheses Test

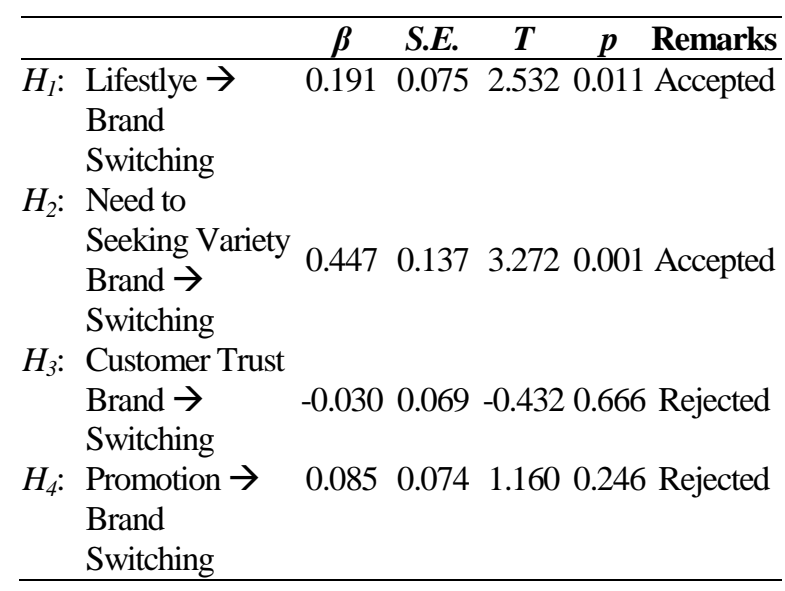

\section{Discussion}

The result of this study shows that customer trust has a negative but not significant influence on brand switching. The result of this study is different than the previous study (Gunawan, 2013). On the study result of Gunawan (2013) explains that customer trust has a positive influence on brand switching, while in this study customer trust on a certain smartphone brand should not encourage the customer to switch brand on its competitor's brand. The higher level of trust on a certain brand it will lower the desire to switch brands. When customer trust increased in a certain brand, then customer retention tow switch brand will improve (Ranaweera \& Jaideep, 2003). Trust is the most important part in the context of generation Y (Valentine \& Power, 2013), especially in behaviour influence (Lu, Zhao \& Wang, 2010). The trust will make customer loyal to its brand (Reisenwitz \& Iyer, 2009).

Lifestyle is able to affect switch brand significantly. The previous study explains it can make the customer continuously shopping (Ahmad, Omar \& Ramayah, 2010). This study explains that when a customer focuses on lifestyle, then they will not easy to turn away from the certain brand. Generation $\mathrm{Y}$ is the generation that prioritizes on social image trends (Twenge \& Campbell, 2008). Generation Y is not afraid to spend their money on a quality brand (Goldg- ehn, 2004) and able to represent their personality (Lazarevic, 2012). Rajamma, Pelton, Hsu, and Knight (2010) believed that a brand that can influence consumer behaviour from generation $\mathrm{Y}$ is a brand that is able to meet the needs of self-expression. Some experts explain that self-expression is part of consumer's lifestyle (O'cass \& Siahtiri, 2013; Phau \& Cheong, 2009). They will switch to another smartphone brand if it qualified and present their personalities.

Variety seeking is able to influence brand switching significantly. This result is the same as Rajagopal (2005) opinions, where variety seeking becomes the main trigger key on brand switching. The Limited option will make consumers tend to choose one brand or loyal to a particular brand. The more choices in customers mind will lead to the confusion. Consumers tend to have a wide range of option since they are influenced by boredom on certain brands (Inman, 2001; Jang \& Feng, 2007; Van Trijp et al., 1996) and desire to be optimally stimulated (Steenkamp \& Baumgartner, 1995). Hedonic needs (feelings of joy and satisfaction) are an important aspect of the variety seeking construct.

Promotion is not able to increase switching brand significantly, One of the reasons, in this study is more focus on traditional promotions is because generation $\mathrm{Y}$ is one of the generation who prefer non-traditional promotional methods. Advertising and others way of promotion is not easy to affect generation Y behaviour (Goldgehn, 2004). Generation Y is a generation who love the digital environment, therefore the way to communicate product should focus on the internet. Generation Y purchasing behaviour is influenced by social media (Bolton et al., 2013). Generation Y have a tendency to interact and influenced through social media (Palfrey \& Gasser, 2008) and they are searching for product information through the internet, therefore a non-internet way of promotion will not able to encourage the generation $\mathrm{Y}$ to has a desire to switch brand.

\section{Conclusion}

The purpose of this study is to examine the trigger factors of brand switching behaviour in generation $\mathrm{Y}$, especially in the smartphone industry. In this research there are four driving factors. Those are lifestyle, variety seeking, customer trust and promotion. The results of this study indicate that the most important factor for generation $\mathrm{Y}$ in making brand switching is needed to express lifestyle and variety seeking.

In this study, there are some managerial implycations. First, the traditional way of promotion is un- 
able to make customers switch brand. Generation Y likes stimulation through unusual ad campaigns, focusing on internet media promotion. Social media is the best medium for generation $\mathrm{Y}$, such as a promotion that is able to express the customer's lifestyle. In this study found that lifestyle being able to make customers switch to other brands. Generation Y likes the trendy lifestyle. Second, companies should be able to produce a variety of products. The results of this study explain the desire to find various alternatives can make customer switch brands. Companies are required to create product variation in one segments, it because when a customer sees a brand with multiple product alternatives, the customer will not switch to another brand. Customer will not look for another brand, because in one brand already provide several options of products that can be used as an alternative.

Theoretical implications in this study are generation $\mathrm{Y}$, an unpredictable generation in the context of brand switching. The customer trust in a certain brand it should be able to reduce brand switching behaviour on the competitor brand, while in this study the effect is not significant. This study also found that promotion by the company can increase customer behaviour in switching brands, but promotion is not the main thing in creating a switching barrier. It can be concluded that generation $\mathrm{Y}$ is unpredictable in the context of brand switching.

In this study there are still limitations because there are two goodness of fit parameter value is still marginal fit that is AGFI and GFL. Suggestion for further research are as follows: (1) adding several important variables that will affect the brand switching, such as product usage, customer experience, and involvement; (2) Using gender as a variable moderator; (3) Change lifestyle dimension and promotion.

\section{References}

Ahmad, N., Omar, A., \& Ramayah, T. (2010). Consumer lifestyles and online shopping continuance intention. Business Strategy Series, 11(4), 227243.

Al-Kwifi, O. S., \& Ahmed, Z. U. (2015). An intellectual journey into the historical evolution of marketing research in brand switching behavior past, present and future. Journal of Management History, 21(2), 172-193.

Al-Kwifi, O. S., Ahmed, Z. U., \& Yammout, D. (2014). Brand switching of high-technology capital products: how product features dictate the switching decision. Journal of Product \& Brand Management, 23(4/5), 322-332.
Al-Kwifi, O. S. \& McNaughton, R. (2011). A model of brand switching by lead users of high-tech capital equipment. International Journal of Technology Marketing, 6(3), 199-212.

Anderson, E. W. \& Sullivan, M. (1993). The antecedents and consequences of customer satisfaction for firms. Marketing science, 12(125-143).

Arianto, A. B. (2011). Pengaruh atribut produk, harga, kebutuhan mencari variasi, dan ketidakpuasan konsumen terhadap keputusan perpindahan merek dari samsung galaxy series di kota Malang. Jurnal Aplikasi Manajemen, 11(2), 294-305.

Atkinson, S. \& Butcher, D. (2003). Trust in managerial relationships. Journal of Managerial Psychology, 18(4), 282-304.

Bagozzi, R. P. \& Yi, Y. (1988). On the evaluation of structural equation models. Journal of the Academy of Marketing Science, 16(1), 74-94.

Belch, G. E. \& Belch, M. A. (2001). Advertising and Promotion (5th ed.). USA: McGraw Hill.

Bolton, R. N., Parasuman, A., Hoefnagels, A., Migchels, N., Kabadayi, S., Gruber, T., \& Solnet, D. (2013). Understanding generation $\mathrm{Y}$ and their use of social media: A review and research agenda. Journal of Service Management, 24(3), 245-267.

Chen, M. F. \& Huang, C. H. (2013). The impacts of the food traceability system and consumer involvement on consumers' purchase intentions toward fast foods. Food Control, 33(2), 313319.

Dharmmesta, B. S. (1991). Azas-Azas Marketing. Yogyakarta: Liberty.

Ghozali, I. (2013). Model persamaan struktural: Konsep dan aplikasi dengan program AMOS 21. Semarang: Universitas Diponegoro.

Goldgehn, L. A. (2004). Generation who, what, Y? What you need to know about generation Y. International Journal of Educational Advancement, 5(1), 24-34.

Gonzalez, A. M. \& Bello, L. (2002). The construct "lifestyle" in market segmentation: The behavior of tourist consumers. European Journal of Marketing, 36(1/2), 51-85.

Greenwood, M. \& Van Buren III, H. J. (2010). Trust and stakeholder theory: Trustworthiness in the organisation-stakeholder relationship. Journal of Business Ethics, 95(3), 425-438.

Gunawan, F. (2013). Pengaruh persepsi merek dan kepercayaan konsumen atas produk terhadap brand switching atas produk smartphone (blackberry) pada mahasiswa UNP. Jurnal Manajemen, 2(1), 1-11. 
Ha, J., \& Jang, S. S. (2013). Variety seeking in restaurant choice and its drivers. International Journal of Hospitality Management, 32(March), 155-168.

Inman, J. J. (2001). The role of sensory-specific satiety in attribute-level variety seeking. Journal of Consumer Research, 28(1), 105-120.

Jang, S. S. \& Feng, R. (2007). Temporal destination revisit intention: The effects of novelty seeking and satisfaction. Tourism Management, 28(2), 580-590.

John, G., Weiss, A. M., \& Dutta, S. (1999). Marketing in technology-intensive markets: Toward a conceptual framework. Journal of Marketing, 63(1), 78-91.

Kahn, B. E. (1995). Consumer variety-seeking among goods and services: An integrative review. Journal of Retailing and Consumer Service, 2(3), 139-148.

Kahn, B. E. \& Louie, T. A. (1990). Effects of retraction of price promotions on brand choice behavior for variety seeking and last-purchase-loyal consumers. Journal of Marketing, 27(3), 279289.

Khan, S. \& Nasr, M. (2011). Impact of lifestyle of Pakistani women on their buying behavior. International Review of Business Research Papers, 7(2), 292-309.

Khrisnan, J. (2011). Lifestyle: A tool for understanding buyer behavior. International Journal of Economics and Management, 5(1), 283-298.

Kotler, P. \& Armstrong, G. (2008). Prinsip-prinsip pemasaran. Jakarta: Erlangga.

Laksana, F. (2008). Manajemen pemasaran. Yogyakarta: Graha Ilmu.

Lau, G. T. \& Lee, S. H. (1999). Consumers' trust in a brand and the link to brand loyalty. Journal of Market Focused Management, 4(4), 341-370.

Lazarevic, V. (2012). Encouraging brand loyalty in fickle generation Y consumers. Young Consumers, 13(1), 45-61.

Lin, C. \& Lin, Y.T. (2008). Robust analysis on promotion duration for two competitive brands. The Journal of the Operational Research Society, 59(4), 548-555.

Lin, L. \& Shih, H. (2012). The relationship of university students' lifestyle, money attitude, personal value and their purchase decision. International Journal of Research in Management, 1(2), 19-37.

Lopez, J. P. M., Redondo, Y. P., \& Olivan, F. J. S. (2006). The impact of customer relationship characteristics on customer switching behavior: Differences between switchers and stayers. Managing Service Quality, 16(6), 556-574.
Lu, Y., Zhao, L., \& Wang, B. (2010). From virtual community members to $\mathrm{C} 2 \mathrm{C}$ e-commerce buyers: Trust in virtual communities and its effect on consumers' purchase intention. Electronic Commerce Research and Applications, 9(4), 346-360.

Maixé-Altés, J. C. (2010). Competition and choice: Banks and savings banks in Spain. Journal of Management History, 16(1), 29-43.

McAlister, L. \& Pessemier, E. (1982). Variety seeking behavior: An interdisciplinary review. Journal of Consumer Research, 9(3), 311-322.

Meixner, O. \& Knoll, V. (2015). Integrating price promotions into the switch of brands model for approximating variety-seeking behaviour. British Food Journal, 117(2), 588-603.

Menon, S. \& Kahn, B. E. (1995). The impact of context on variety-seeking in product choices. Journal of Consumer Research, 22(3), 285-295.

Moorman, C., Deshpande, R., \& Zaltman, G. (1993). Factors affecting trust in market research relationships. Journal of Marketing, 57(1), 81-101.

Mowen, J. C. \& Minor, M. S. (2002). Consumer Behavior. Upper Saddle River, NJ: Prentice Hall Inc.

Muskat, M., Muskat, B., Zehrer, A., \& Johns, R. (2013). Generation Y: Evaluating services experiences through mobile ethnography. Tourism Review, 68(3), 55-71.

Nunnally, J. C. (1978). Phsycometric. New York: McGraw-Hill.

O'cass, A. \& Siahtiri, V. (2013). In search of status through brands from Western and Asian origins: Examining the changing face of fashion clothing consumption in Chinese young adults. Journal of Retailing and Consumer Service, 20(6), 505515.

Palfrey, J. \& Gasser, U. (2008). Born digital: Understanding the first generation of digital natives. New York: Basic Book.

Parmen, A. (2013). Generation Y vs. baby boomers: Shopping behavior, buyer involvement and implications for retailing. Journal of Retailing and Consumer Service, 20(2), 189-199.

Peter, T. (1987). Triving on chaos. New York: Alfred A. Knopf.

Phau, I. \& Cheong, E. (2009). How young adult consumers evaluate diffusion brands: Effects of brand loyalty and status consumption. Journal of International Consumer Marketing, 21(2), 109123.

Ping, R. A. (1993). The effects of satisfaction and structural constraints on retailer exiting, voice, loyalty, opportunism, and neglect. Journal of Retailing, 69(3), 320-352. 
Plummer, J. T. (1974). The concept and application of lifestyle segmentation. Journal of Marketing, $38(1), 33-37$

Porral, C. C., \& Levy-Mangin, J.P. (2016). Food private label brands: the role of consumer trust on loyalty and purchase intention. British Food Journal, 118(3), 679-696.

Rajagopal, S. (2005). Influence of brand name in variety seeking behavior of consumers: An empirical analysis. Departement of Marketing, Business Division. Monterrey Institute of Technology and Higher Education, ITESM Mexico City Campus. Mexico.

Rajamma, R. K., Pelton, L. E., Hsu, M. K., \& Knight, D. K. (2010). The impact of consumers' need for uniqueness and nationality on generation Y's retail patronage behaviors: Investigating American and Taiwanese consumers. Journal of Global Marketing, 23(5), 387-410.

Ranaweera, C. \& Jaideep, P. (2003). The influence of satisfaction, trust and switching barriers on customer retention in a continuous purchasing setting. Journal of Service Industry Management, 14(4), 374-395.

Reisenwitz, T. H. \& Iyer, R. (2009). Differences in generation $\mathrm{X}$ and generation Y: Implications for the organization and marketers. The Marketing Management Journal, 19(2), 91-103.

Sari, D. P., Hidayat, W., \& Widiartanto. (2014). Pengaruh lifestyle, efek komunitas, dan fitur produk terhadap keputusan brand switching smartphone blackberry ke merek lain. Jurnal Ilmu Administrasi Bisnis, 3(4), 1-9.

Shukla, P. (2004). Effect of product usage, satisfaction and involvement on brand switching behaviour. Asia Pacific Journal of Marketing and Logistics, 16(4), 82-104.

Soares, A. M., Pinho, J. C., \& Nobre, H. (2012). From social to marketing interactions: The role of social networks. Journal of Transnational Management, 17(1), 45-62.

Solka, A., Jackson, V. P., \& Lee, M. (2011). The influence of gender and culture on Generation $Y$ consumer decision making styles. The International Review of Retailing Distribution and Consumer Research, 21(4), 391-409.
Solomon, M. R. (2011). Consumer behavior: Buying, having, and being. Upper Saddle River, NJ: Pearson.

Srinivasan, N. \& Ratcford, B. T. (1991). An empirical test of a model of external search for automobiles. Journal of Consumer Research, 18(2), 233242.

Steenkamp, J. B. E. M. \& Baumgartner, H. (1995). Development and cross-cultural validation of a short form of CSI as a measure of optimum stimulation level. International Journal of Research in Marketing, 12(2), 97-104.

Sun, B. (2005). Promotion effect on endogenous consumption. Marketing science, 24(3), 430443.

Syrett, M. \& Lammiman, J. (2004). Advertising and millennials. Young Consumers: Insights and Ideas for Responsible Marketing, 15(4), 62-84.

Twenge, J. M. \& Campbell, S. M. (2008). Generational differences in psychological traits and their impact on the workplace. Journal of Managerial Psychology, 23(8), 862-877.

Valentine, D. B. \& Power, T. L. (2013). Generation Y values and lifestyle segments. Journal of Consumer Marketing, 30(7), 597-606.

Van Trijp, H. C. M., Hoyer, W. D., \& Inman, J. J. (1996). Why switch? Product category: Level explanations for true variety-seeking behavior. Journal of Marketing Research, 33(3), 281-292.

Viswanathan, V. \& Jain, V. (2013). A dual-system approach to understanding "generation $\mathrm{Y}^{\mathrm{N}}$ decision making. Journal of Consumer Marketing, 30(6), 484-492.

Wathne, K. H., Biong, H., \& Heide, B., J. (2001). Choice of supplier embedded markets relationship and marketing program effects. Journal of Marketing, 65(2), 54-66.

Yap, B. W., Ramayah, T., \& Shahadin, N. W. (2012). Satisfaction and trust on customer loyalty: A PLS approach. Business Strategy Series, 13(4), 154-167. 